九州大学学術情報リポジトリ

Kyushu University Institutional Repository

\title{
Willingness to Pay for Organic Vegetables in Vietnam : An Empirical Analysis in Hanoi capital
}

Hai, Ngo Minh

Laboratory of Food Marketing and Distribution, Department of Agricultural and Resource Economics, Faculty of Agriculture, Graduate School of Bioresource and Bioenvironmental Sciences, Kyushu University

Moritaka, Masahiro

Faculty of Agriculture, Kyushu University

Fukuda, Susumu

Faculty of Agriculture, Kyushu University

森高，正博

九州大学大学院農学研究院

https://doi.org/10.5109/27378

出版情報 : 九州大学大学院農学研究院紀要. 58 (2)，pp.449-458，2013-09. Faculty of Agriculture， Kyushu University

バージョン:

権利関係: 


\title{
Willingness to Pay for Organic Vegetables in Vietnam: An Empirical Analysis in Hanoi capital
}

\section{Ngo Minh HAI ${ }^{1}$, Masahiro MORITAKA ${ }^{2 *}$ and Susumu FUKUDA ${ }^{2}$}

\author{
Laboratory of Food Marketing and Distribution, Division of Agricultural and Resource Economics, \\ Department of Agricultural and Resource Economics, Faculty of Agriculture, \\ Kyushu University, Fukuoka 812-8581, Japan \\ (Received April 26, 2013 and accepted May 9, 2013)
}

\begin{abstract}
High levels of pesticide and chemical fertilizer inside vegetables are always risky to Vietnamese people in general, Hanoi's people in particular when only about 30\% of the area for vegetable production in Hanoi are controlled and safely certified by the government. The consumers still become worried, even some of them do not totally trust the safe vegetables because the chemical residue, pesticide levels are difficult to fully check and control due to insufficient capability of the state's agencies. Organic vegetables known as no chemical pesticide and no synthetic fertilizer bring a new choice for consumers. This study aims at evaluating current status of organic vegetables consumption and eliciting consumers' willingness to pay for organic ones in big cities like Hanoi in Vietnam. A sample of 185 respondents surveyed at four big supermarkets in Hanoi was analyzed by descriptive statistics and Contingent Valuation Method (CVM) under double bounded dichotomous choice approach. These results found that about 15\% of the consumers already had experience of using organic vegetables, however, eighty-eight percent wanted to try and buy if organic products exist in the market. Major reasons for the limitation in consumption of the organic foods were the lack of information about organic market, inconvenience to buy. Average price paid for organic vegetables was about 70\% higher than that of conventional ones. Besides, the consumers who had higher income, more concern about safety of vegetables, and organic-consumed experience in the past would be likely to pay more for organic vegetables. These findings suggest that information about organic vegetables should be widely publicized to consumers and that new organic vegetables shops opened are priority to expand organic market share in the future.
\end{abstract}

Key words: consumer demand, contingent valuation method, organic food, organic vegetables, willingness to pay

\section{INTRODUCTION}

Issues related to food safety and hygiene become increasingly important toward Vietnamese people, particularly the urban consumers (Simmons and Scott, 2008), even among the most concern issues in Vietnam (Sarter et al., 2012). A survey about consumers' perception of safe vegetables in Vietnam found that vegetables were the most important in their daily meal (VINATAS, 2011). However, only 30\% of the production area in Hanoi for safe vegetables was legally certified by the government (calculation from Tam, 2010; Hanoi People Committee, 2012). Moreover, due to the government's limitation, controlling of the chemical pesticide and synthetic fertilizer has been difficult. Therefore, some consumers even do not trust about the safe vegetables (i.e. under VietGAP or Global GAP standard) when they still think that the chemical pesticides still exit inside vegetables (Phuong, 2010). Doubt of consumers toward safety of certified labeled vegetables was also found in Thailand (Roitner-Schobesberger et al., 2008).

Laboratory of Food Marketing and Distribution, Department of Agricultural and Resource Economics, Faculty of Agriculture, Graduate School of Bioresource and Bioenvironmental Sciences, Kyushu University, Japan.

${ }^{2}$ Faculty of Agriculture, Kyushu University, Fukuoka 812-8581, Japan

* Corresponding author (E-mail: m-moritaka@agr.kyushu-u. ac.jp)
An introduction of organic farming opens new opportunities for producers and especially for consumers. Having officially established since the mid 1990s, yet organic farming has still been a new concept in Vietnam (Voan, 2006). Up to 2011, organic production area only reached about 23.4 thousand ha, which comprised about $0.23 \%$ of the total agricultural production land (excluding forestry land and surface area for fishing) in Vietnam (FiBL and IFOAM, 2013). Among the area for organic production, only 200 ha for organic vegetables was produced in Hanoi, Hoa Binh, Bac Ninh, Vinh Phuc, Lam Dong, Ho Chi Minh and so on (Vietnam Farmer Union, 2012). In recent years, developing organic agriculture has been more paid attention from the government when a National Basic Standard for Organic Products in Vietnam was released in 2006, followed by establishing Vietnam Organics Association in 2011. However, due to the lack of market information and the absence of certification system, Vietnamese consumers are still confused the concept of organic food and they cannot distinguish between organic and safe products (Sautier, 2012; Vietnam Farmer Union, 2012). This may be considered the biggest barrier for expanding organic market share in Vietnam.

Although a large number of studies on organic consumers in Europe and other Western countries like the U.S were introduced, those studies in Asia countries are few (Roitner-Schobesberger et al., 2008). Compared with other countries in the Southeast Asia region such as Thailand or the Philippines, studies on organic agricul- 
ture in Vietnam are even limited, especially in terms of consumer demand. Some previous researches about organic foods in Vietnam were usually approached under an overview of production and business of organic foods (Nhan, 2011; Hoa, 2009; Anh and Thuan, 2005) while others focused on links or value chains of organic vegetables (Sautier, 2012; Vietnam Farmer Union, 2012). A report about consumers' willingness to pay toward organic products estimated that Hanoi's consumers were ready to pay higher premium over conventional ones (Huong, 2007). However, Huong's study which only elicited the consumers' demand by descriptive statistics analyses could not identify the factors influencing the consumers' WTP. Hence, in the present study, we hypothesize that consumers in Hanoi are likely to pay higher amount for organic vegetables although few of them already bought organic foods. Furthermore, prices, income, consumers' concerned issues, organic-consumed experience, perception of chemical level, education and age are likely to influence on WTP. Our study applying Contingent Valuation Method (CVM) with double bounded technique was used to estimate WTP and also to show factors affecting WTP toward organic vegetables in Hanoi, Vietnam.

\section{MATERIALS AND METHODS}

\section{Data collection}

A face-to-face interview with consumers was undertaken at four big supermarkets around the center of Hanoi including Savico Megamall, Big C, Metro and Fivimart in September and October 2012. Only consumers who have been working and have income were sampled. The distribution of respondent over Savico Megamall, Big C, Metro and Fivimart supermarkets are 50, 50, 49 and 36 respectively. The questionnaire structure mentioned three aspects: (1) information related to actual buying toward organic vegetables or not; (2) consumers' demand as well as their behavior and attitudes for organic vegetables; (3) general information about social-economic and demographical characters of consumers. After receiving 202 respondents, we checked that the number of valid sample size was 185 .

\section{Analysis methods}

First, descriptive statistics and bivariate analyses were used to evaluate the current status of organic vegetables consumption in Hanoi. This method will provide general background about the percentage of consumers who already bought organic vegetables. Besides, reasons for no buying organic vegetables as well as their demands to easily access organic markets are also explored.

Next, to elicit consumers' willingness to pay for organic vegetables we applied contingent valuation method (CVM), which helps to find out how much an individual would be willing to pay by using hypothetical survey questions (Mitchell and Carson, 1989). CVM has widely expanded into many fields such as recreation, hunting, water quality (Mitchell and Carson, 1989) to health economics, transportation safety and cultural eco- nomics (Venkatachalam, 2004). Recent period, researches about organic food were also applied by Ara (2002), Rodríguez et al. (2007) and others. Specific techniques in CVM include bidding games, payment cards, open-ended and dichotomous choice. This study uses double bounded dichotomous choice contingent valuation method (DBDC CVM) because it favors for saving time in surveying at supermarkets and has more efficiency as well as more information than single bounded approach (Hanemann et al., 1991). Many recent researches were also deployed double bounded choice such as Ara (2002), Rodríguez et al. (2007), Abdullah and Jeanty (2011) and Claudy et al. (2011).

In double bound approach, respondents will be asked by two questions. Question format will be "Are you willing to pay amount of money for organic vegetable that is no chemical, no synthetic fertilizer, no chemical pesticide and good for health" Each question has two choices: yes or no. If saying "yes" in the first question, higher amount of bid will be given in the second question; otherwise, lower amount with saying "no". Therefore, one of four abilities of a respondent can be: Yes-Yes (yy), Yes-No (yn), No-Yes (ny), No-No (nn).

According Hanemann (1991), the probability of answering "Yes" for both questions is expressed

$$
\begin{aligned}
\operatorname{Pr}_{y y}\left(B, B^{u}\right) & =\operatorname{Pr}\left[B \leq W T P, B^{u} \leq W T P\right] \\
& =\operatorname{Pr}\left[B \leq W T P \mid B^{u} \leq W T P\right] \operatorname{Pr}\left[B^{u} \leq W T P\right] \\
& =\operatorname{Pr}\left[B^{u} \leq W T P\right]=1-F\left(B^{u}\right)
\end{aligned}
$$

where $\operatorname{Pr}_{\mathrm{yy}}$ : the probability of answering "Yes" "Yes" $\mathrm{B}$ : the price in the first question $\mathrm{B}^{\mathrm{u}}$ : the higher price in the second question WTP: Willingness to Pay

F : Cumulative Distribution function (CDF) The probability of answering "Yes" followed by answer "No" in question 2 is

$$
\operatorname{Pr}_{y n}\left(B, B^{u}\right)=\operatorname{Pr}\left[B \leq W T P<B^{u}\right]=F\left(B^{u}\right)-F(B)
$$

Similarly, probabilities for answers "No-Yes" and "No No" are:

$$
\begin{aligned}
& \operatorname{Pr}_{n y}\left(B, B^{d}\right)=\operatorname{Pr}\left[B^{d} \leq W T P<B\right]=F(B)-F\left(B^{d}\right) \\
& \operatorname{Pr}_{n n}\left(B, B^{d}\right)=\operatorname{Pr}\left[B>W T P, B^{d}>W T P\right]=F\left(B^{d}\right)
\end{aligned}
$$

where $\mathrm{B}^{\mathrm{d}}$ : lower price in the second question To estimate the likelihood of responses, maximum likelihood estimation is applied. Given a sample of $\mathrm{N}$ respondents, where $\mathrm{B}_{\mathrm{i}}, \mathrm{B}_{\mathrm{i}}^{\mathrm{u}}, \mathrm{B}_{\mathrm{i}}^{\mathrm{d}}$ are bids used for the $\mathrm{i}^{\text {th }}$ respondent, the log-likelihood function will be:

$$
\begin{aligned}
\ln L & =\sum_{1}^{N}\left\{y y_{i} \ln P r_{Y Y}\left(B_{i}, B_{i}^{u}\right)+y n_{i} \ln P r_{Y N}\left(B_{i}, B_{i}^{u}\right)\right. \\
& \left.+n y_{i} \ln \operatorname{Pr}_{N Y}\left(B_{i}, B_{i}^{d}\right)+n n_{i} \ln P r_{N N}\left(B_{i}, B_{i}^{d}\right)\right\}
\end{aligned}
$$

where yy, yn, ny and nn are dummy variables. If one respondent say yes-yes (yy) for two questions, then yy=1, so others will be zero.

Next step is to choose a model for eliciting WTP. Interval- data model (standard double bounded model) by Hanemann (1991) is chosen. WTP is generally expressed by function: 


$$
W T P_{i j}=\alpha+\beta B i d_{i j}+\lambda Z_{i}+\varepsilon_{i j}
$$

where $\alpha$ : intercept of the model

Bid is proposed price given to respondents (hypothetical price)

$\beta$ : the coefficient of Bid

$Z_{i}$ : the vector of socio-economic demographic variables of consumer $i_{\text {th }}$ (see more in Table 1 )

$\lambda$ : the coefficients of $\mathrm{Z}_{\mathrm{i}}$

$\mathrm{i}$ : individual consumer $\left(\mathrm{i}^{\text {th }}\right)$

$\mathrm{j}$ : kind of vegetables

Vegetables used in this research are tomato and choy sum because they are popular to Vietnamese at survey period. All variables are defined in Table 1. Expected signs show hypotheses that our study propose.

In Table 1 there is a need to clearly define some variables including edu1, edu2, income and expenditure. Firstly, edu1 includes respondents who gained from 13 to 16 schooling-years, while edu2 consists of those who studied above 16 years. Secondly, income levels are classified: level 1 if average income per household a month is under 8 million VND (under 400 USD), level 2 from 8 million VND to 15 million VND (400 to 750 USD), and level 3 above 15 million VND (above 750USD) ${ }^{1}$. Finally, the identification of daily expenditure levels for vegetables of one household is level 1 for an amount under 10 thousand VND, level 2 from 10 to 20 thousand VND, level 3 above 20 to 30 thousand VND, and level 4 above 30 thousand VND.

Table 1. Variables of the double bounded logit model

\begin{tabular}{|c|c|c|}
\hline Variables & Description of variables & $\begin{array}{l}\text { Expected } \\
\text { Sign }(+/-)\end{array}$ \\
\hline \multicolumn{3}{|c|}{ Dependent variable } \\
\hline Resp & Response to bid: receives 1 if answer "yes" with proposed bid amount, 0 if saying "no" & \\
\hline \multicolumn{3}{|c|}{$\underline{\text { Independent variables }}$} \\
\hline Bid & Hypothetical price of organic vegetable & - \\
\hline Safety & Consumer evaluation about vegetable safety (linkert-scale: $1=$ very unsafe, $5=$ =very safe) & - \\
\hline Chemical & Evaluation about chemical pesticide \& fertilizer (linkert-scale: 1=very high, 5=very low) & - \\
\hline Concerned_issue & The most important issue for buying vegetable ( $0=$ price, $1=$ others) & + \\
\hline Label_recog & Recognition about label or origin of vegetable ( 1 =never, $2=$ sometimes, $3=$ always) & + \\
\hline Orga_cons & Organic vegetable consumption before $(0=\mathrm{No}, 1=\mathrm{Yes})$ & + \\
\hline Age & Age of respondents (years) & + \\
\hline Gender & Respondents' gender ( $0=$ male, $1=$ female) & + \\
\hline Edu1 & Respondents' education ( 1 =undergraduate, $0=$ otherwise) & + \\
\hline Edu2 & Respondents' education (1-post graduate, $0=$ otherwise) & + \\
\hline Hhsize & Household size (number of family's member) & + \\
\hline Income & Monthly income of households (3 levels: $1=$ lowest, 3 = highest) & + \\
\hline Expenditure & Daily expenditure for vegetables ( 4 levels: $1=$ lowest, $4=$ highest) & + \\
\hline Savi_code* & Savico supermarket (dummy variable: 1 -Savico supermarket, 0-otherwise) & + \\
\hline Bigc_code & BigC supermarket (dummy variable: 1-Big C supermarket, 0-otherwise) & + \\
\hline Metro_code & Metro supermarket (dummy variable: 1-Metro supermarket, 0-otherwise) & + \\
\hline Fivi_code & Fivimart Supermarketdummy variable: 1-Fivimart supermarket, 0-otherwise) & + \\
\hline
\end{tabular}

Note: * omitted dummy variable out of running the model

Table 2. Bid system for tomato and choy sum in Hanoi

\begin{tabular}{|c|c|c|c|c|c|}
\hline \multicolumn{3}{|c|}{ Tomato's Bid (VND) } & \multicolumn{3}{|c|}{ Choy sum's Bid (VND) } \\
\hline $1^{\text {st }}$ bid & High bid & Low bid & $1^{\text {st }}$ bid & High bid & Low bid \\
\hline 18,000 & 24,000 & 12,000 & 14,000 & 20,000 & 8,000 \\
\hline 22,000 & 28,000 & 16,000 & 18,000 & 24,000 & 12,000 \\
\hline 26,000 & 32,000 & 20,000 & 22,000 & 28,000 & 16,000 \\
\hline 30,000 & 36,000 & 24,000 & 26,000 & 32,000 & 20,000 \\
\hline 34,000 & 40,000 & 28,000 & 30,000 & 36,000 & 24,000 \\
\hline
\end{tabular}

1 The identification of ranging income level was based on the calculation of average income from VHLSS (GSO, 2010) for Hanoi's household. Of which, mean income was 402 USD/household/month, five income quintiles were 108 USD, 206 USD, 301 USD, 447 USD, 917 USD. 
The parameter of equation (1) would be estimated by running the maximum likelihood estimation of $\mathrm{lnL}$ above, using STATA 10.0. In order to identify mean and median WTP, as well as confidence interval, Krinsky and Robb (1986) procedure, applied by Abdullah (2009) and Claudy (2011) is deployed with the commands of Jeanty (2007) using for STATA.

\section{Payment vehicle designing (bid designing)}

In this study, designing hypothetical prices (bids) to apply double bound dichotomous was based on the pretest and the prices of the conventional vegetables in the supermarkets $(15,000 \mathrm{VND} / \mathrm{kg}$ for choy sum and $20,000 \mathrm{VND} / \mathrm{kg}$ for tomato) in September and October 2012. Bidding system was used in Table 2. Each consumer will be asked for answering one of five random bids set above to minimize the bias of starting bids.

\section{RESULTS}

Socio-demographic characteristics of respondents and the current status of organic vegetables con-

\section{sumption}

The result in Table 3 shows that 15\% of the consumers had experience of buying organic vegetables in Hanoi at least one time (organic buyers) before the survey conducted. Average age of organic buyers was higher than that of consumers who had not bought organic vegetables yet (organic non-buyers). Seventy-five percent of the respondents were women and the gender's difference was non-significant between the organic buyers and nonbuyers. In generally, over 50\% of the consumers were undergraduates or attained college/university degrees. Although education of the organic buyer seemed higher than that of the non-buyer, these differences had no statistical significance. Meanwhile, the consumers who had experience of purchasing organic foods gained higher income than non-users.

Among 117 consumers hearing or understanding about organic vegetables, those who did not buy comprised $77 \%$. Main reasons for limitation in using organic vegetables were summarized in Fig. 1 including no information about organic market, inconvenience to buy. In fact, twenty-two over 27 consumers felt difficult to find

Table 3. Socio-demographic characteristics of respondents

\begin{tabular}{|c|c|c|c|c|}
\hline Variables & $\begin{array}{c}\text { Organic buyers } \\
n=27(15 \%)\end{array}$ & $\begin{array}{l}\text { Organic non-buyers } \\
\quad n=158(85 \%)\end{array}$ & $\begin{array}{c}\text { Sig. of difference } \\
\text { tests }\end{array}$ & $\begin{array}{c}\text { Total } \\
\mathrm{n}=185(100 \%)\end{array}$ \\
\hline Average age (years) & 38.6 & 34.3 & $0.040^{\mathrm{a}}$ & 34.9 \\
\hline Gender & & & $0.409^{\mathrm{b}}$ & \\
\hline Male & $19 \%$ & $26 \%$ & & $25 \%$ \\
\hline Female & $81 \%$ & $74 \%$ & & $75 \%$ \\
\hline Education & & & $0.124^{\mathrm{a}}$ & \\
\hline High school or less & $15 \%$ & $35 \%$ & & $32 \%$ \\
\hline Undergraduate/graduate & $70 \%$ & $50 \%$ & & $53 \%$ \\
\hline Post-graduate & $15 \%$ & $15 \%$ & & $15 \%$ \\
\hline Household income per month $\left(000 \mathrm{VND}^{\mathrm{m}}\right)$ & & & $0.034^{\mathrm{a}}$ & \\
\hline$<8,000$ & $8 \%$ & $28 \%$ & & $25 \%$ \\
\hline $8,000-15,000$ & $59 \%$ & $49 \%$ & & $51 \%$ \\
\hline$>15,000$ & $33 \%$ & $23 \%$ & & $24 \%$ \\
\hline Household size (people) & 3.8 & 4.0 & $0.293^{\mathrm{a}}$ & 4.0 \\
\hline
\end{tabular}

Note: ${ }^{m}$ Exchange interest rate was rounded at 20,000 VND for one USD in September and October 2012.

${ }^{a}$ Wilcoxon rank-sum test, ${ }^{b}$ Chi-square test.

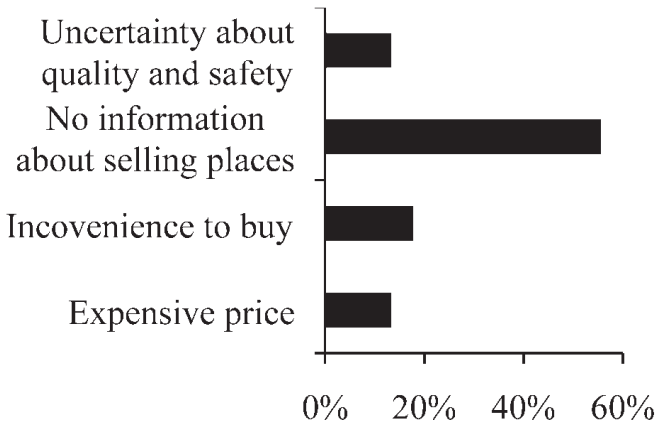

Fig. 1. Reasons for no buying organic vegetables $(n=90)$.

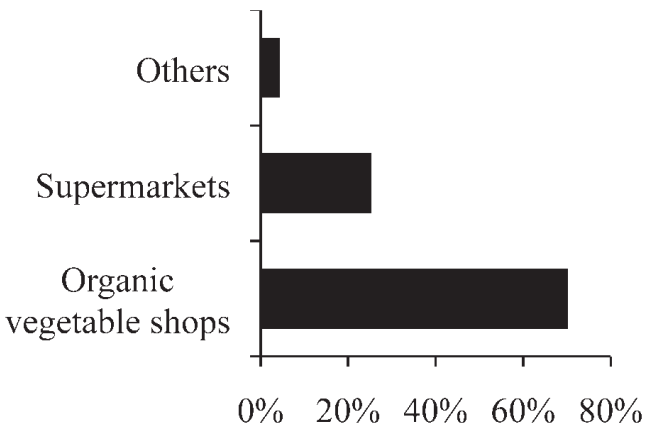

Fig. 2. Percentage choices about organic selling places $(n=185)$. 
and buy organic ones. Fig. 2 indicates that to help consumers easy to access organic market, new organic vegetable shops opened is first priority, followed by more stores in supermarkets.

\section{WTP for organic vegetables and factors affecting WTP}

Table 4 indicates that about $88 \%$ of the consumers wanted to try or buy organic vegetables if these products exist in market, while $12 \%$ were not sure because they had not known about the prices and other buying conditions. Especially, no one refused to try organic vegetables if they have chances after being clearly explained about organic ones.

Besides, the result of from estimating mean/median WTP in Table 5 shows that consumers were willing to pay about 35 thousand VND per kilogram for tomato and about 26 thousand VND per kilogram for choy sum². This means that consumers would pay around 70\% higher for organic vegetables than conventional ones sold in the supermarkets. The estimation also indicates that 95\% confidence interval of higher premium of organic tomato and choy sum ranged from $153 \%$ to $237 \%$, and $155 \%$ to $210 \%$ respectively.

Determinants influencing on the WTP for organic tomato and choy sum from double bounded logit model were presented in Table 6. These results of model for tomato and choy sum shared some same significant factors. For instance, variables including concerned_issue, expenditure, orga_cons, income, and bid were significant toward both two models. However, chemical variable only had effect to choy sum model, not in tomato model. Reversely, label_recog gender, edu2 were only related to WTP of tomato, not significant toward choy sum.

Table 4. Percentage of consumers who are willing to buy if organic vegetables are available

\begin{tabular}{lcc}
\hline & No. respondents & Percent \\
\hline Yes & 163 & 88.1 \\
Unsure/uncertain & 22 & 11.9 \\
No & 0 & 0 \\
Total & 185 & 100 \\
\hline
\end{tabular}

In Table 6 , bid variables which showed negative signs as expected at $1 \%$ level expressed a reverse effect on WTP. Specifically, one-unit decrease in bid would increase odds ratio by $28 \%$ and $23 \%$ in tomato and choy sum models respectively (Table 7). Also, a negative sign of chemical variable toward WTP of choy sum revealed that the consumers would pay more money for organic choy sum if they perceived currently high level of chemical in vegetables. However, this variable showed no significant effect on WTP for tomato product. The estimation clarified that concerned issue had the strongest influence on the consumers' WTP at significant level of

Table 6. Estimates from double bounded logit model for tomato and choy sum

\begin{tabular}{|c|c|c|c|c|}
\hline \multirow{2}{*}{ Measures } & \multicolumn{2}{|c|}{ Tomato } & \multicolumn{2}{|c|}{ Choy sum } \\
\hline & Coefficient & $\mathrm{SE}$ & Coefficient & SE \\
\hline Safety & -0.35 & 0.22 & ------ & ---- \\
\hline Chemical & ----- & ----- & $-0.58 * *$ & 0.24 \\
\hline Concerned_issue & $1.37 * * *$ & 0.47 & $1.26^{* * *}$ & 0.46 \\
\hline Label_recog & $0.51^{*}$ & 0.27 & 0.28 & 0.26 \\
\hline Expenditure & $0.33 *$ & 0.20 & $0.33^{*}$ & 0.19 \\
\hline Orga_cons & $0.89 *$ & 0.53 & $1.20 * *$ & 0.52 \\
\hline Age & 0.03 & 0.02 & 0.00 & 0.02 \\
\hline Gender & $0.70 *$ & 0.36 & 0.51 & 0.35 \\
\hline Edu1 & 0.33 & 0.35 & 0.51 & 0.35 \\
\hline Edu2 & $1.10^{*}$ & 0.57 & 0.82 & 0.56 \\
\hline Hhsize & 0.18 & 0.14 & 0.20 & 0.14 \\
\hline Income & $0.91^{* * *}$ & 0.26 & $0.94 * * *$ & 0.26 \\
\hline Fivi_code & $-1.64 * * *$ & 0.52 & -0.69 & 0.49 \\
\hline Metro_code & -0.57 & 0.46 & -0.21 & 0.47 \\
\hline Bigc_code & -0.54 & 0.44 & -0.20 & 0.43 \\
\hline Constant & 2.15 & 1.45 & $2.71^{* *}$ & 1.35 \\
\hline Bid & $-0.28 * * *$ & 0.02 & $-0.26 * * *$ & 0.02 \\
\hline Number of obs & 185 & & 185 & \\
\hline Log likelihood & -197.08 & & -204.43 & \\
\hline Wald chi2 (14) & $71.48^{* * *}$ & & $67.48^{* * *}$ & \\
\hline FCCC (\%) & 56.22 & & 49.19 & \\
\hline
\end{tabular}

Note: ${ }^{*} p<0.1,{ }^{* *} p<0.05, * * * p<0.01$

Table 5. Mean/median WTP for tomato and choy sum

\begin{tabular}{|c|c|c|c|c|c|c|c|c|}
\hline \multirow[b]{2}{*}{ Measures } & \multicolumn{4}{|c|}{ Tomato (000VND) } & \multicolumn{4}{|c|}{ Choy sum (000VND) } \\
\hline & WTP & $\begin{array}{l}\text { Lower } \\
\text { bound }\end{array}$ & $\begin{array}{l}\text { Upper } \\
\text { bound }\end{array}$ & $\begin{array}{l}\text { \% Organic/ } \\
\text { Conventional } \\
(95 \% \mathrm{CI})\end{array}$ & WTP & $\begin{array}{l}\text { Lower } \\
\text { bound }\end{array}$ & $\begin{array}{l}\text { Upper } \\
\text { bound }\end{array}$ & $\begin{array}{c}\text { \% Organic/ } \\
\text { Conventional } \\
(95 \% \mathrm{CI})\end{array}$ \\
\hline Mean & 39.36 & 32.81 & 88.86 & & 30.89 & 26.14 & 55.98 & \\
\hline Medium & 34.70 & 30.60 & 47.54 & $\begin{array}{l}173 \% \\
(153 \%-237 \%)\end{array}$ & 26.03 & 23.25 & 31.56 & $\begin{array}{l}173 \% \\
(155 \%-210 \%)\end{array}$ \\
\hline
\end{tabular}

Note: Mean and median were computed by applying Krinsky and Robb (95\%) confidence intervals for WTP measures (5000 reps)

\footnotetext{
${ }^{2}$ Median values were chosen to reflect average WTP for tomato and choy sum because they are less affected by outliers than mean values.
} 
Table 7. Influence magnitude of explanatory variables on WTP

\begin{tabular}{|c|c|c|c|c|c|c|}
\hline & \multicolumn{3}{|c|}{ Tomato } & \multicolumn{3}{|c|}{ Choy sum } \\
\hline & Coef. & Exponentiated coef. & \%change in odds & Coef. & Exponentiated coef. & \%change in odds \\
\hline Chemical & & & & -0.58 & 0.56 & -44.0 \\
\hline Concerned_issue & 1.37 & 3.94 & 293.5 & 1.26 & 3.53 & 252.5 \\
\hline Label_recog & 0.51 & 1.67 & 66.5 & & & \\
\hline Expenditure & 0.33 & 1.39 & 39.1 & 0.33 & 1.39 & 39.1 \\
\hline Orga_cons & 0.89 & 2.44 & 143.5 & 1.20 & 3.32 & 232.0 \\
\hline Gender & 0.70 & 2.01 & 101.4 & & & \\
\hline Edu2 & 1.10 & 3.00 & 200.4 & & & \\
\hline Income & 0.91 & 2.48 & 148.4 & 0.94 & 2.56 & 156.0 \\
\hline Fivi_code & -1.64 & 0.19 & -80.6 & & & \\
\hline Bid & -0.28 & 0.76 & -24.4 & -0.26 & 0.77 & -22.9 \\
\hline
\end{tabular}

Table 8. Response distribution

\begin{tabular}{llllll}
\hline & \multicolumn{4}{l}{ Percentage of respondents $(\mathrm{n}=185)$} & \multirow{2}{*}{ Total } \\
\cline { 2 - 5 } & Yes- Yes & Yes-No & No-Yes & No-No & \\
\hline \multirow{2}{*}{ Tomato } & $34.6 \%$ & $35.7 \%$ & $18.4 \%$ & $11.3 \%$ & $100 \%$ \\
Choy sum & $35.7 \%$ & $26.5 \%$ & $26.5 \%$ & $11.3 \%$ & $100 \%$ \\
\hline
\end{tabular}

$1 \%$. When the consumers pay more attention to quality and safety of vegetables than vegetables' prices, probabilities of saying "yes" in WTP question for organic tomato and choy sum will increase by 3 times and 2.5 times respectively (Table 7 ).

Furthermore, Table 7 also indicates the WTP of consumers who already bought organic vegetables would be two to three times as high as that of organic non-buying ones. Important economic variables including average expenditure and income were also found to be significant as economic theory at $10 \%$ and $1 \%$ respectively. The calculation of Table 7 implies that odd ratios about WTP rose by $150 \%$ when income increased one thousand VND.

In this study, consumer behavior about label recognition also had positive influence on WTP toward organic tomato at $1 \%$ significance, but not on WTP of choy sum. Different consumers' characters such as gender and education were also found to be statistically significant only on tomato model, but choy sum one. For instance, the results in Table 6 and 7 showed that female and postgraduate consumers would have higher probability in buying organic tomato with percent change in odd ratios of $100 \%$ and $200 \%$ respectively. Although geographical location of Hanoi's consumers was not directly mentioned in this study, fivi_code variable (expressing consumers interviewed in Fivimart supermarket) found to be significant might explain difference about WTP in different areas.

In order to evaluate the performance and goodnessof-fit of the models, Wald test and Fully, Correctly, Classified Cases (FCCC) by Kanninen and Khawaja (1995) were used. First, Wald tests for tomato and choy sum which had significance at 1\% level show that explanatory variables were generally suitable. Continuously, FCCC was applied to evaluate the fitness. This method will fully and correctly classify each observation into one of four categories "yes - yes", "yes - no", "no - yes" or "no - no", and then calculate the percentage. The highest FCCC will be chosen among models. Also, the authors also point out one criterion called "maximum chance" to judge the FCCC value. Following this approach, if a model' FCCC is higher than maximum chance criterion denoting Cmax, the model could be considered for acceptance.

We found that $C \max$ values from Table 8 were $35.7 \%$ both tomato and choy sum models, while FCCC were $56.2 \%$ and $49.2 \%$ for tomato and choy sum models respectively (Table 6). Hence, the two proposed models for tomato and choy sum were appropriate.

\section{DISCUSSION}

The study found that only few consumers in Hanoi used organic vegetables. One of the most important reasons was the lack of information about organic market. This percentage of using organic products from buyers is fairly similar to that of India with 9\% (Garibay and Jyoti, 2003). This result, however, is small compared with 33\% in Indonesia (Wahida et al., 2012), 39\% in Bangkok (Roitner-Schobesberger et al., 2008) and 55\% in Chiang Mai - Thailand (Somsak and Blut, 2012). Main reasons for organic share limitation may be due to the lack of information, knowledge about organic ones, and other factors (Garibay and Jyoti, 2003). Despite of limitation in current market share, consumers' demand for organic product is high in Hanoi. The results about high percentage of willingness to pay show consistence with other studies such as Ara (2002), Huong (2007), Dipeolu et al. (2009), Wahida et al. (2012), and Somsak and Blut (2012). For example, Huong (2007) reported that 93\% of 
Vietnamese consumers had a high desire for organic vegetables. In a study about WTP for organic vegetables in West Africa, $85 \%$ of the consumers in Ghana and $95 \%$ in Benin agreed to buy a higher price for organic vegetables (Coulibaly et al., 2011).

In this study, the average premium WTP, 70\% higher for organic over conventional vegetables, was higher than that of Huong's calculation (2008). According to Huong's estimation, about $48 \%$ of the consumers were likely to pay $50 \%$ or higher levels for organic than for conventional vegetables. This difference can be partly explained by differences in sampling area when our study was conducted in only Hanoi, while Huong's research involved Hanoi and Haiphong. This average WTP, however, is also consistent with those of Rodríguez et al. (2007) reporting a higher premium of $87 \%$, and Coulibaly et al. (2011) showing premium from $50 \%$ to $66 \%$. Coulibaly et al. (2011) estimated that consumers were likely to pay a premium of over $50 \%$ for organic vegetables.

Regarding factors influencing on WTP, consumers' concern about their health found to be the most important motivation to trying organic vegetables in this study is also similar to the result of Somsak et al. (2012). Roitner-Schobesberger et al. (2008), Sangkumchaliang and Huang (2012) also identified that consumers' expectation of good health was main reason to buy organic food. Income of consumers also has high impact on consumers' demand for organic food. The positive effect of income on WTP in our study is supported by Kalashami et al. (2012), Somsak et al. (2012), Rodríguez et al. (2007), Dettmann \& Dimitri (2007), and Akgüngör et al. (2010). Roitner - Schobesberger et al. (2008) found that respondents who already bought organic vegetables had higher income than those who had not bought them. Other studies, however, showed no relationship between income and consumer's decision to buy organic foods (Basarir and Gheblawi, 2012; Li et al., 2007).

Further, the finding that consumers already used organic vegetables would be more willing to buy than non-consumers coincides with the results of Rodríguez et al. (2007), Basarir and Gheblawi (2012), and Wahida et al. (2012). This result may reveal the loyalty of consumers and recommend one way to increase the demand if producers have appropriate marketing channels. Households' daily expenditure for vegetables was also found to be positively significant at $10 \%$ in both organic tomato and choy sum. Household expenditure which, in theory, may have positive relationship with income was found to less correlated with family's revenue. This issue may be explained by Vietnamese household's behavior in which people usually use vegetables in daily meal regardless of income level. Basarir and Gheblawi (2012) also reported that consumers who had higher income and weekly expenditure on fruits and vegetables would be likely to pay more for organic ones.

Consumer's evaluation about chemical residue in conventional choy sum had an inverse effect on organic purchasing-decision. When they recognize high risk of chemical pesticide to their health, they want to find safer kinds. The effect of chemical pesticide on WTP which was only found in choy sum, not tomato may be due to different perceptions about chemical levels inside each kind of products. For instance, consumers may think that choy sum - a leafy vegetable is easily contaminated by chemical than tomato that is partly protected through its skin. This effect of pesticide residue has consistence with the result of Coulibaly et al. (2011) in which Ghana's consumers would be more likely to buy organic cabbage if their perception about pesticide usage is high. These authors' finding, however, identified that pesticide residue also influenced on WTP for tomato. Contrary to this study, a negative effect of pesticide's perception on consumers' demand for organic vegetables was found in the finding of Rodríguez et al. (2007).

Different effects of factors to various kinds of vegetables became clearer when label recognition, gender and education were considered in the study. Specifically, higher label recognition, female and post-graduate education level positively influenced only the consumers' demand on tomato, not on choy sum'. First, impact of label recognition which had no relationship with WTP in both cabbage and tomato products (Coulibaly et al., 2011) was only significant at $5 \%$ in tomato model, not choy sum in this study. Rodríguez et al. (2007) also reported that label recognition effected on WTP of organic products such as chicken and aromatic herbs, but not leafy vegetables. By observing the labels of various products in the supermarkets, we recognized that the tomato was packed well with clear label, whereas the choy sum, a kind of leafy vegetable, was tightened by lines with unclear information about the origin. This might infer that products with clear labels could increase their reliability to persuade consumers. Second, women who paid more for organic products than men in Wahida et al (2012)'s study were found to be significant in this finding. A positive impact of women on WTP also came from findings by Jolly (1991), Buzby et al. (1994). However, relationship between gender and demand for organic foods seemed to be unclear (Owusu and Anifori, 2013; Li et al., 2007; Cranfield and Magnusson, 2003). In this study, gender also only affected WTP for tomato, not choy sum. Therefore, it should be conservative to conclude the impact of gender to organic demand. Similarly, consumers who had post-graduate degrees positively influenced WTP only on organic tomato, not on organic choy sum in our study. Results from Dettmann and Dimtri (2007), Akgüngör et al. (2010) and Kalashami et al. (2012) also identified that higher education consumers obtained would had higher demand on organic food. Two studies about organic food in Thailand also estimated higher demand for highly educated consumers (Sangkumchaliang and Huang, 2012; RoitnerSchobesberger et al., 2008). Other findings, whereas, showed no significance (Owusu and Anifori, 2013; Li et al., 2007; Cranfield and Magnusson, 2003) or even negative effect (Misra et al., 1991; Buzby and Skees, 1994). An inverse relation between education and organic food demand was also found in the finding of Basarir and Gheblawi (2012). Especially, impact of education could reversely vary among demands on different organic prod- 
ucts or graphical areas in the same one research. This case was mentioned in the study of Coulibaly et al. (2011), in which one negative sign of education on WTP was found in cabbage model in Ghana, but positive one for cabbage in Benin. Furthermore, education had no impact on WTP of organic tomato in both Ghana and Benin (Coulibaly et al., 2011). Therefore, there may not be enough evidence to clarify a direct relationship between education level and demand on organic foods.

Contrary to our hypotheses, respondents' ages and their household size did not affect the demand on organic vegetables in this study. No evidence about impact of age on WTP was consistent with the estimates of Basarir and Gheblawi (2012), Owusu and Anifori (2013), Wahida et al. (2012) or Jolly (1991). However, Cranfield and Magnusson (2003) found that younger consumers (less than 35 years old) would be likely to buy more organic foods. Similarly, a higher demand on freepesticide food belonged to young consumers (van Ravenswaay and Hoehn, 1991; Buzby and Skees, 1994). Ara (2002) only found a negative relationship between age and WTP for organic rice in Naga, not in Manila of the Philippines. Reversely, three studies in Thailand showed that consumers who bought organic food tended to be older than non-buyers (Somsak and Blut, 2012; Roitner-Schobesberger et al., 2008; Sangkumchaliang and Huang, 2012). Another finding suggested younger people (aged 16-30) and the older (over 50 years old) would have higher demand on organic food, so one inverse U-shape distribution should be considered to express relationship between age and WTP (Xia and Zeng, 2008). Finally, household size which was not related to consumers' demand on organic vegetables also has no signal from the findings of Coulibaly et al. (2011), Basarir and Gheblawi (2012), Bhatta et al. (2009), Piyasiri and Ariyawardana (2002). Meanwhile, few studies found significant relationship between family size and WTP (Xia and Zeng, 2008).

The present study was done in big supermarkets in Hanoi whose consumers usually have higher income than that of the people around Hanoi as well as Vietnam as a whole; as a result, these estimates may not be generalizable to the small cities, rural areas. Another better way to generalize these results is to supplement samples from small cities and rural areas in the future. Besides, we only evaluated the consumer's willingness to pay for organic vegetables, not all organic foods, so the high amount of consumers' demand may be not fully correct for other organic ones.

Nevertheless, our study is considered the first comprehensive approach about organic foods' demand in Vietnam and has important marketing as well as policy implications. A high demand for organic foods indicates high potentials for the development of organic food in this country. This is also consistent with the report of Lan (2010), which showed that supply of organic vegetables could not meet demand. The results provide some useful recommendations to the government who wants to expand the organic market share. Specifically, providing information widely about organic vegetables with their unique characters compared with conventional ones may be the most important task next time. It is necessary to help Vietnamese people to differentiate between organic and safe vegetables because many people do not know about organic food and they are still confused with safe products (Phuong, 2010). To persuade consumers to believe in the quality and safety of organic vegetables, the government should support and encourage organizations or institutions that provide certification and label for organic foods, such as Participatory Guarantee System (PGS) certification now for organic vegetables. Furthermore, the findings about consumers' factors influencing on WTP for organic vegetables also give important messages to retailers. A clear label with full information about organic vegetables will help them to understand well about organic character and benefits. Second, retailers may increase their share of organic market through opening new shops, attracting new customers through old consumers who already used organic ones. Finally, market segmentation by income groups should be considered to utilize consumers' demand and enlarge organic market share.

\section{CONCLUSIONS}

These findings show that market share of organic vegetables is very small because most of people have no adequate information about organic market, inconvenience to buy or uncertainty about quality and safety of organic foods. However, majority of Hanoi's consumers would be likely to pay higher price for organic over conventional vegetables. Most important factors that influence on WTP for organic vegetables are their concerned issues (price or safety and quality), income and organic consumed experience. Organic vegetable shops become the first priority choice of Hanoi's consumers to try and buy organic products.

\section{ACKNOWLEDGEMENT}

This study was supported by Japan's Grant Aid for Human Resources Development Scholarship (JDS) Program. We would like to thank Mr. Tran Manh Hai and Ms. Thai Thi Nhung for their assistance in the interview of participants. We also thank Hanoi University of Agriculture, Vietnam for providing necessary documents to conduct the survey.

\section{REFERENCES}

Abdullah, S. and P. W. Jeanty 2011 Willingness to pay for renewable energy: Evidence from a contingent valuation survey in Kenya. Renewable and Sustainable Energy Reviews, 15: 2974-2983

Akgüngör, S., B. Miran, and C. Abay 2010 Consumer Willingness to Pay for Organic Food in Urban Turkey. Journal of International Food \& Agribusiness Marketing, 22: 299-313

Anh, N. H. and N. T. Thuan 2005 Organic vegetables in sub-area of Hanoi. Journal of Science and Development, Hanoi University of Agriculture, issue 5

Ara, S. 2002 Environmental Evaluation of Organic Rice: A Case 
Study in the Philippines. M. S Thesis, 2002. [http://www.shihomiaksoy.org/shihomi/MAThesis.pdf]

Basarir, A. and M. S. Gheblawi 2012 Analyzing demand and consumers' willingness to pay for organic fruits and vegetables. Journal of Food, Agriculture \& Environment, 10(3\&4): 86-91

Bhatta, G. D., W. Doppler and K. K. C. Bahadur 2009 Potentials of Organic Agriculture in Nepal. The Journal of Agriculture and Environment, vol. 10

Buzby, J. C. and J. R. Skees 1994 Consumers want reduced exposure to pesticides on food. Food Review, 17(2): 19-26

Claudy, M .C., C. Michelsen and A. O'Driscoll 2011 The diffusion of microgeneration technologies - assessing the influence of perceived product characteristics on home owners' willingness to pay. Energy Policy, 39: 1459-1469

Coulibaly, O., T. Nouhoheflin, C. C. Aitchedji, A. J. Cherry and P. Adegbola 2011 Consumers' Perceptions and Willingness to Pay for Organically Grown Vegetables. International Journal of Vegetable Science, 17(4): 349-362

Cranfield, J. A. L. and E. Magnusson 2003 Canadian Consumer's Willingness -To-Pay for Pesticide Free Food Products: An Ordered Probit Analysist. International Food and Agribusiness Management Review, 6(4)

Dettmann, R. L. and C. Dimitri 2007 Organic Consumers: A Demographic Portrayal of Organic Vegetable Consumption within the United States. Contributed Paper prepared for presentation at the $105^{\text {th }}$ EAAE seminar, International Marketing and International Trade of Quality Food Product, Bologna, Italy, March 8-10, 2007

FiBL (Research Institute of Organic Agriculture), IFOAM (International Federation of Organic Agriculture Movements) 2013 Organic agricultural land and share of total agricultural land (including conversion land) by country 2005-2011. [http://www.organic-world.net]. Last update March 22, 2013

Garibay, S. V. and K. Jyoti 2003 Market Opportunities and challenges for Indian Organic products. [http://orgprints.org/ 2684/1/garibay-2003-Market-Study-India.pdf]. Accessed March $2^{\text {nd }} 2013$

Hanemann, M., J. Loomis and B. Kanninen 1991 Statistical Efficiency of Double-Bounded Dichotomous Choice Contingent Valuation. American Journal of Agriculture Economics, 73(4): 1255-1263

Hanoi People Committee. Report No. 12/2012/BC-UBND.

Hoa, L. T. 2009 Development and Perspective of Organic Agriculture in Vietnam. Organic Symposium in Nonthaburi, Thailand in January $3^{\text {rd }} 2009$

Huong, N. M. 2007 Consumers demands for organic agricultural products. Presentation at the Malica seminar 2007 on Recent changes affecting quality in Vietnam food consumption and chains-institutional challenges and methods, Hanoi, December $11-12,2007$

Jeanty, P. W. 2007 Constructing Krinsky and Robb Confidence Intervals for Mean and Median Willingness to Pay (WTP) Using Stata. $6^{\text {th }}$ North America Stata Users' Group Meeting, August 13-14, 2007. Boston, MA

Jolly, D. A. 1991 Determinants of Organic Horticultural Products Consumption Based on a Sample of California Consumers. Acta Horticulture, 295: 141-148

Kalashami, M. K., M. Heydari and H. Kazerani 2012 Investigating Consumers' Willingness to Pay for Organic Green Chicken in Iran (Case study: Rasht City). International Journal of Agricultural Management \& Development, 2(4): 235-241

Krinsky, I. and A. L. Jobb 1986 On Approximating the Statistical Properities of Elasticities. Review of Economics and Statistics, 68: 715-719

Lan, T. 2010 Safe and Sound. Vietnam Economic Times, Special Report, Feb. 2010, pp. 26-27

Li, J. L. and B. W. Gould 2007 The demand for organic food in the U.S: An Empirical Assessment. Journal of Food Distribution Research, $\mathbf{3 8}(3)$

Misra, S. K., C. L. Huang and S. L. Ott 1991 Consumer Willingness to Pay for Pesticide-Free Fresh Produce. Western Journal of
Agricultural Economics, 16(2): 218-227

Mitchell, R. C. and R. T. Carson 1989 Using Surveys to Value Public Goods: The Contingent Valuation Method. Research for the Future, Washington D. C, The Johns Hopkins Univ. Press, pp. 2-12

Nhan, M. T. 2011 Study on production and business of organic vegetables of the farmers in Thanh Xuan commue, Soc Son district, Hanoi city. Undergraduate thesis in 2011. Hanoi University of Agriculture

Owusu, V. and M. O. Anifori 2013 Consumer Willingness to Pay a Premium for Organic Fruit and Vegetable in Gana. International Food and Agribusiness Management Review, $\mathbf{1 6}(1)$

Phuong, T. D. 2010 Back to nature. Vietnam Economic Time. February 2010, pp. 28

Piyasiri, A. G. S. A. and A. Ariyawardana 2002 Market Potentials and Willingness to Pay for Selected Organic Vegetables in Kandy. Sri Lankan Journal of Agricultural Economics, 4(1): 107-119

Rodríguez, E., V. Lacaze and B. Lupín 2007 Willingness to Pay for organic food in Argentina: Evidence from a consumer survey Contributed Paper prepared for presentation at the $105^{\text {th }}$ EAAE seminar, International Marketing and International Trade of Quality Food Product, Bologna, Italy, March 8-10, 2007

Roitner-Schobesberger, B., I. Darnhofer, S. Somsook and C.R. Vogl 2008 Consumer perceptions of organic foods in Bangkok, Thailand. Food Policy, 33: 112-121

Sangkumchaliang, P. and W. C. Huang 2012 Consumers' Perceptions and Attitudes of Organic Food Products in Northern Thailand. International Food and Agribusiness Management Review, 15(1)

Sarter, S., H. P. Ha and T. K. Anh 2012 Current situation of food safety in Vietnam. The $1^{\text {st }}$ FOODSEG Symposium, Berlin, Germany, 21-22 June 2012

Sautier, D. 2012 Challenges and Opportunities in the development of organic vegetable value chain. Report in The conference of Developing Organic Vegetables Value Chain In Vietnam, May $8^{\text {th }} 2012$, Vietnam

Simmons, L. and S. Scott 2008 Organic Agriculture and "Safe" Vegetables in Vietnam: Implications for Agro-Food System Sustainability. [http://www.oacc.info/Docs/Guelph2008Social Sciences/Simmons\%20and\%20Scott\%20\%282008\%29.pdf] Accessed March $18^{\text {th }} 2013$

Somsak, P. and M. Blut 2012. Organic Vegetable Consumption In A Region of Thailand (Chiang Mai): Evaluation of Consumers Perception And Consumer Buying Behavior. Clute Institute International Conference - March 2012

Tam, D. D. 2010 Study on solutions for the sustainable development of safe vegetable in Hanoi. A PhD thesis in Hanoi University of Agriculture, Vietnam

van Ravenswaay, E. and J. P. Hoehn 1991 Consumer Willingness to Pay for Reducing Pesticide Residues in Food. Results of a Nationwide Survey. Agricultural Economics Staff Paper 91-18, Michigan State University

Venkatachalam, L. 2004 The Contingent valuation method: a review. Environmental Impact Assessment Review, 24 $89-124$

Vietnam Farmer Union 2012 Analyzing Organic Vegetables Value Chain in Vietnam, Report in The conference of Developing Organic Vegetables Value Chain In Vietnam, May $8^{\text {th }} 2012$ Vietnam

VINATAS (Vietnam Standard and Consumer Association) 2011 http://www.nguoitieudung.com.vn/main/index.php?action= News\&do=1\&id=272\#.UUb8sTfheSo. Accessed March $2^{\text {nd }}$ 2013

Voan, V. L. Y. 2006 Organic production in Vietnam. Forum of International Organic Agriculture, Taiwan 2006. [http://info, organic.org.tw/supergood/ezcatfiles/organic/img/img/1085/ 372463538.pdf]. Accessed March $2^{\text {nd }} 2013$

Wahida, W. J. Umberger, N. Minot, R. Stringer and H. Toiba 2012 Exploring Indonesian Consumers' Demand for Certified Organic and Pesticide-Free Agricultural Products. Paper presented at 
the $56^{\text {th }}$ AARES Annual Conference, Fremantle, Western Australia, February 7-10, 2012

Xia, W. and Y. C. Zeng YC 2008 Consumer's Willingness to Pay for
Organic Food in the Perspective of Meta-analysis. International Conference on Applied Economics-ICOAE 2008 